\title{
Paper-based inoculum of Bacillus megaterium and its practical application for simple culture preparation
}

\author{
Mana Kanjanamaneesathian* and Wasunan Nimanong \\ Faculty of Animal Science and Agricultural Technology, Silpakorn University, Phetchaburi IT \\ campus, Cha-Am, Phetchaburi, 76120, Thailand \\ *Corresponding author: Kanjanamaneesat_m@su.ac.th
}

\begin{abstract}
The bacterium Bacillus megaterium can be used to biologically control sheath blight and grain discoloration in rice. Large-scale inoculations using liquid cultures are cumbersome so the efficacy of an alternative, paper-based system was examined. Bacterial endospores were embedded on filter papers and multiplied using a simple culture technique. The resulting suspension was used to pre-soak yardlong bean and cucumber seeds before sowing to assess its effect on seed germination and weight. The efficacy of the bacterium in protecting cucumber seeds from pre-emergent damping-off was also examined. The population of bacteria embedded in paper declined initially but remained stable for 150 days at room temperature. Bacterial culture reduced seed germination of cucumber and seedling weight of yardlong beans. Dilution with water either increased or reduced germination of cucumber seeds depending on concentration. A 1:10 v/v dilution increased cucumber-seed germination in a pre-emergent damping-off pot test but all seedlings later died, irrespective of treatment. Paper-based inoculum has the potential to replace liquid inoculum but further work is required to optimise the concentrations of the bacterial culture to achieve disease control without adversely affecting the host plant.
\end{abstract}

Keywords biological control agent, damping-off of seedlings, seed germination

\section{INTRODUCTION}

Bacillus megaterium, originally isolated from rice paddy soil, is an effective bacterial biological control agent (BCA) against Rhizoctonia solani, a causal agent of sheath blight disease in rice (Oryza sativa) (Kanjanamaneesathian et al. 1998; Pengnoo et al. 2000). Bacillus megaterium has also been shown to be effective against Fusarium sacchari, and Curvularia lunata, two of the main causal agents of rice grain discoloration disease (Kanjanamaneesathian et al. 2009).

Bacillus megaterium has been formulated into floating pellets (Wiwattanapatapee et al. 2004), effervescent granules (Wiwattanapatapee et al. 2007), water-soluble granules (Chumthong et al. 2008), alginate microcapsules (Wiwattanapatapee et al. 2013) and spray-dried powder (Chumthong et al. 2016). As part of the product-development process, the efficacy of these formulations was tested in both greenhouse and small fieldplot trials (Wiwattanapatapee et al. 2004; Wiwattanapatapee et al. 2007; Wiwattanapatapee et al. 2013; Chumthong et al. 2016).

The water-soluble granules were effective in suppressing rice blast caused by Pyricularia oryzae, and rice grain discoloration, probably because this formulation contained a high number of viable endospores of $B$. megaterium (Kanjanamaneesathian et al. 2009). Utilisation of this product was facilitated by two agencies: the Department of Pharmaceutical Technology, Faculty of Pharmaceutical Sciences, Prince of Songkla University, Hat Yai, Songkhla and the local office of the Department of Agricultural Extension (DOAE), Ministry of Agriculture and Agricultural Cooperatives, Amphur Muang, 
Uttaradit, Thailand. These formulations were originally produced in small quantities for research purposes and have never been adopted for large-scale commercialisation despite their proven efficacy (Chumthong et al. 2008). This is because biocontrol products generally have very small share of Thailand's plant pest and disease control market (Warburton et al. 2002). A small quantity of water-soluble granules remained available at the local office of the DOAE, Uttaradit province but the amount was insufficient to distribute to rice farmers for use in subsequent growing seasons. It is too labour intensive and, therefore, expensive to produce more granules on a large scale. Therefore, fresh cell suspension of $B$. megaterium and simple technique in culturing this bacterium were used to replace the water-soluble granules and nutrient broth (NB) (Kanjanamaneesathian \& Meetum 2019).

In an effort to promote the use of $B$. megaterium, the local office of the DOAE, Uttaradit, has championed the use of the remaining two $\mathrm{kg}$ of water-soluble granules as an inoculum to produce a cell suspension of $B$. megaterium (Kanjanamaneesathian \& Meetum 2017).

Fresh B. megaterium cell suspension produced at the Faculty of Animal Science and Agricultural Technology, Silpakorn University, Phetchaburi IT campus, Cha-Am, Phetchaburi, was used as an alternative inoculum starter to produce more cell suspensions of $B$. megaterium, replacing the water-soluble granules, due to the continued need of the rice farmers at Amphur Muang, Uttaradit for use in rice fields. However, liquid inoculum of $B$. megaterium is cumbersome to use because it requires transportation and storage of large quantities of liquids, careful handling, and exact application techniques (Kanjanamaneesathian \& Meetum 2017). In addition, rice farmers are expected to culture $B$. megaterium in their households, subjecting the liquid inoculum to contamination.

Rice farmers have traditionally relied on rice as their main cash crop but they have also grown fruit trees and vegetables [such as yardlong bean (Vigna unguiculata) and cucumber (Cucumis sativus)] for extra income and daily household consumption (Warburton et al. 2002). It will be important, therefore, that the preparation of biopesticides be sufficiently versatile to be used for controlling diseases in these crops as well. For these reasons, the development of a novel formulation for the inoculum of $B$. megaterium is required that is convenient to use in order to replace the liquid inoculum and thereby facilitate the supply chain and adoption of this BCA by the rice growers. The ease-of-use of the inoculum to produce the fresh cell culture of the bacterium should also expand its use on other crops, such as yardlong bean and cucumber. These vegetables are susceptible to soil-borne plant pathogenic fungi, such as Pythium ultimum, Fusarium sp. and Rhizoctonia sp. (Agrios 2005).

Chilvers et al. (1986) employed stiff absorbent paper card to produce the inoculum of Pisolithus tinctorius and Paxillus involutus, two fungi that are the important ectomycorrhizas of eucalypt seedlings (Eucalyptus globulus Subsp. bicostata). This paper-based inoculum was effective in initiating the symbiotic relationship between these fungi and the peripheral roots of seedlings grown in peat-moss within clay pots. More recently, Malusá et al. (2012) reviewed the technologies used to produce the inoculum of beneficial microorganisms. In this review, the authors acknowledged that the formulation of inoculum with a reliable and consistent performance for application in the field is still a bottleneck. The selection of the technology for producing the inoculum and the type of materials used as the carrier for the formulation is the key to effective application.

Filter paper is a common material that is readily available and can be easily sterilised with autoclave in the laboratory. This filter paper is commercially available making it a potentially suitable carrier of beneficial microorganisms as there is a continuous supply, should large scale production of the paper-based inoculum of $B$. megaterium be required.

The objectives of this present research were to: (1) determine the viability of the endospores of $B$. megaterium on paper during storage under two types of conditions; (2) investigate the use 
of paper-based inoculum of $B$. megaterium as a starter to produce fresh cell cultures of $B$. megaterium based on a simple culture system (Kanjanamaneesathian \& Meetum 2017); and (3) assess the efficacy of this simple culture of $B$. megaterium in promoting seed germination and preventing disease in certain vegetables.

\section{MATERIALS AND METHODS}

\section{Preparation of endospores of $B$. megaterium}

A pure culture of $B$. megaterium (Kanjanamaneesathian et al. 1998) was used to prepare the endospores, which were, in turn, used to prepare the paper-based inoculum. A loopful of the bacterium was first cultured statically (without any agitation) in $400 \mathrm{~mL}$ of nutrient broth [NB $\left(\right.$ Difco $\left.\left.^{\mathrm{Tx}}\right)\right]$ at $37^{\circ} \mathrm{C}$ in an incubator for 24 hours before transferring $1-\mathrm{mL}$ aliquots of the culture into separate sterile potato dextrose agar (PDA; HIMEDIA ${ }^{\circledR}$, India) prepared in 250$\mathrm{mL}$ capacity Erlenmeyer flasks. These flasks were swirled to ensure the distribution of the liquid culture on the surface of a PDA medium. The bacterial cultures in the flasks were incubated at $37^{\circ} \mathrm{C}$ for four days, after which $50 \mathrm{~mL}$ of sterile water were added to prepare the cell suspension of B. megaterium .

The fresh cells were harvested from the surface of the PDA medium in the flasks using a sterile stirring glass rod and the suspension transferred into 50-mL centrifugal tubes.

The cell suspension was centrifuged at 3,000 revolutions per minute for 10 minutes, after which the supernatant was discarded and the resultant pellet was suspended in 30-mL sterile water. The centrifugation and cell-washing process was repeated three times to remove any residual culture medium.

The tubes of cell suspensions were placed in a water bath at $80^{\circ} \mathrm{C}$ for 10 minutes. The supernatant containing dead vegetative cells of $B$. megaterium was discarded and the viable endospores of $B$. megaterium, which remained at the bottom of the tubes, were collected. The viable endospores were stored in a sterile bottle at $5^{\circ} \mathrm{C}$ for further use in the preparation of paperbased inoculum of B. megaterium.
Preparation of paper-based inoculum of $B$. megaterium

Circular cellulose filter papers (Grade 1, Whatman ${ }^{\oplus}$ ) were used as the substrate for the paper-based inoculum of $B$. megaterium. Each filter-paper disc was cut into small pieces $(1 \mathrm{~cm}$ x $5 \mathrm{~cm}$ ), sterilised in an autoclave at $121^{\circ} \mathrm{C}$ for 20 minutes, and dried in a hot air oven at $105^{\circ} \mathrm{C}$ for 24 hours. Seven pieces of sterile dried filter paper were then placed in a sterile Petri dish and $300 \mu \mathrm{L}$ of the endospore suspension of $B$. megaterium (prepared as described above) at $6.1 \times 10^{10} \mathrm{CFU} / \mathrm{mL}$ was aseptically dispensed onto each paper piece. After the endospore suspension had been thoroughly absorbed by the pieces of filter paper, they were dried in the hot air oven at $45^{\circ} \mathrm{C}$ for 48 hours. Sterile dried filter papers without the endospore suspension treatment were used as nil control. The pieces of filter paper inoculated with the endospores of $B$. megaterium were stored either in a sterile Petri dish or wrapped with sterile aluminum foil and kept in a zip-lock plastic bag and stored at room temperature $\left(26-32^{\circ} \mathrm{C}\right)$.

Every 15 days over a period of 150 days, a random paper strip was removed from storage and submerged in a test tube containing $9 \mathrm{~mL}$ of sterile water. The suspensions were agitated with vortex to dislodge the bacterial endospores before they were serially diluted $\left(10^{-2}\right.$ to $\left.10^{-10}\right)$. An aliquot $(100 \mu \mathrm{L})$ of each dilution was spread onto plate count agar (PCA; HIMEDIA ${ }^{\circledR}$, India) containing casein enzyme hydrolysate, yeast extract, dextrose and agar) in Petri dishes in triplicate, and the dishes were incubated at $37^{\circ} \mathrm{C}$ for 24 hours. The number of the viable endospores was then counted and recorded as colony forming units $(\mathrm{CFU}) /$ strip of paper (dimension $1 \mathrm{~cm} \mathrm{x} 5 \mathrm{~cm}$ ).

At time zero, the number of bacteria on the paper was at $4 \times 10^{8} \mathrm{CFU} / \mathrm{mL}$ (for the paper stored in a Petri dish) and was at $9 \times 10^{8} \mathrm{CFU} / \mathrm{mL}$ (for the paper stored in a zip-lock plastic bag).

Preparation of paper-based inoculum for scanning electron microscope observation The stability and viability of $B$. megaterium endospores on the paper strips after storage 
for 135 days was investigated using a scanning electron microscope (SEM; Hitachi SU8020) situated at the Scientific Equipment and Research Division, Kasetsart University, Bangkok, Thailand. Samples of the paper-based inoculum that had been stored in either a sterile Petri dish or in a zip-lock plastic bag were observed. The samples were fumed with $2 \% \mathrm{OsO}_{4}$ for seven hours, after which they were placed in a desiccator (with silica as desiccant) for seven days. After this time, the strips were removed, mounted on stubs and coated with platinum $(\mathrm{Pt})$ particles $(5-\mathrm{nm}$ thickness) then viewed with SEM. Micrographs of the samples were taken at 500x, 1,000x, 3,000x, 5,000x and 9,000x magnification.

\section{Preparation of a simple culture of $B$. megaterium using paper-based inoculum}

A simple culture of B. megaterium was prepared as described by Kanjanamaneesathian and Meetum (2017), with two modifications: (a) common household flavour enhancer (CHFE) replaced NB (Kanjanamaneesathian \& Meetum 2019); and (b) paper-based inoculum was used instead of water-soluble granules containing $B$. megaterium.

Bacillus megaterium was cultured in triplicate by adding an inoculated $1 \mathrm{~cm} \times 5 \mathrm{~cm}$ paper strip $\left(1.7 \times 10^{4} \mathrm{CFU} /\right.$ strip of paper, previously stored in a zip-lock bag) into a translucent plastic drinking water tank $(6 \mathrm{~L})$ containing $5 \mathrm{~g}$ of a common household flavour enhancer, CHFE (Knorr brand, Unilever, Thailand), and $5 \mathrm{~L}$ of commercially available bottled (in $6 \mathrm{~L}$ capacity bottle) potable drinking water (filtered by reverse osmosis (RO), and sterilised with ultra-violet and ozone treatment with $\mathrm{pH}=6.6$ ). The CHFE is composed, by weight, of $40 \%$ iodised salt, $31.9 \%$ monosodium glutamate, $13 \%$ palm oil, $8 \%$ sugar, $3.8 \%$ dehydrated pork meat, $1.5 \%$ soy sauce, $1.4 \%$ spice, and $0.4 \%$ concentrated pork broth. A piece of filter paper $(1 \mathrm{~cm} \times 5 \mathrm{~cm})$ containing the dried endospores of $B$. megaterium, $\left(1.7 \times 10^{4} \mathrm{CFU}\right)$ previously wrapped with sterile aluminum foil in a zip-lock plastic bag, was added to the water tank. The culture was aerated using an aquarium air pump. The air tube was inserted into the tank through a cotton wool plug to prevent contamination. The cultures were incubated for four days at room temperature $\left(25-32^{\circ} \mathrm{C}\right)$ for further use.

\section{Determination of bacterial growth}

The number of bacteria $(\mathrm{CFU} / \mathrm{mL})$ in the simple cultures was assessed after 1, 3, 5, 7 and 9 days from the time $B$. megaterium had been added, by using the spread plate technique on PCA plates in triplicate after incubation at room temperature $\left(37^{\circ} \mathrm{C}\right)$ for 24 hours.

Testing the efficacy of the simple culture of $B$. megaterium in promoting seed germination and seedling growth

A three-day-old simple culture of $B$. megaterium $\left(1.8 \times 10^{6} \mathrm{CFU} / \mathrm{mL}\right)$ was used to assess its efficacy as a seed treatment on promoting germination and seedling growth of yardlong bean and cucumber. Seeds of yardlong bean and cucumber were soaked in bacterium suspension at various dilutions for 12 hours in beakers before sowing onto either sterile moistened papers placed in plastic boxes to mimic a moist chamber condition (i.e. moist-chamber test), or sterile sand in trays (i.e. sand-tray test).

In the moist-chamber test, there were four treatments as follows: (1) seeds of yardlong bean soaked in $100 \mathrm{~mL}$ of un-diluted bacterial cell suspension; (2) seeds of yardlong bean soaked in $100 \mathrm{~mL}$ of sterile water; (3) seeds of cucumber soaked in $100 \mathrm{~mL}$ of un-diluted bacterial cell suspension; and (4) seeds of cucumber soaked in $100 \mathrm{~mL}$ of sterile water. Each treatment had four replications (with 100 seeds per replication).

In the sand-tray test, there were seven treatments as follows: (1) seeds of cucumber soaked in $100 \mathrm{~mL}$ of sterile water; (2) seeds of cucumber soaked in $100 \mathrm{~mL}$ of the mixture of bacterial cell suspension and water (at 1:5 v/v); (3) seeds of cucumber soaked in $100 \mathrm{~mL}$ of the mixture of bacterial cell suspension and water (at $1: 10 \mathrm{v} / \mathrm{v}) ;(4)$ seeds of cucumber soaked in 100 $\mathrm{mL}$ of the mixture of bacterial cells suspension and water (at 1:15 v/v); (5) seeds of cucumber soaked in $100 \mathrm{~mL}$ of the mixture of bacterial cells 
suspension and water (at 1:20 v/v), (6) seeds of cucumber soaked in $100 \mathrm{~mL}$ of the mixture of bacterial cells suspension and water (at 1:25 v/v); and (7) seeds of cucumber soaked in $100 \mathrm{~mL}$ of the mixture of bacterial cell suspension and water (at $1: 30 \mathrm{v} / \mathrm{v}$ ). Each treatment had ten replications (with five seeds per replication).

After 7 days of incubation at room temperature $\left(25-32^{\circ} \mathrm{C}\right)$, seed germination was assessed. Dry weights of the seedlings were obtained after air drying in a hot air oven at $100^{\circ} \mathrm{C}$ for 24 hours.

Testing the efficacy of simple culture of $B$. megaterium to protect cucumber seeds from pre-emergent damping-off

The simple culture was also tested to determine its potential to protect cucumber seeds from infection by the causal agents of a pre-emergent damping-off disease (such as those caused by Pythium sp., Fusarium sp. and Rhizoctonia sp.) that might present in the soil used to raise seedlings in pots that had been placed on a bench in the shade $\left(23^{\circ} \mathrm{C}\right.$ to $\left.33^{\circ} \mathrm{C}\right)$. This soil has no history of damping-off disease of seedlings of any species. It was collected from an area under the canopy of banana [Saba banana (Musa acuminata $\times$ Musa balbisiana)] where there was no other vegetation in Cha-Am municipality, Cha-Am, Phetchaburi, Thailand. The collected soil sample was sieved using a plastic screen $(2$ x $2 \mathrm{~mm}$ pore size) to remove large plant debris. This soil sample was submitted to and analysed in a laboratory by staff of the local office of the Land Development Department at Phetchaburi and Ratchaburi, Ministry of Agriculture and Agricultural Cooperatives, Thailand. The soil characteristics included $\mathrm{pH}=7.1, \mathrm{EC}=0.20$ $\mathrm{dS} / \mathrm{m}, \mathrm{OM}=2.9 \%$, total $\mathrm{N}=0.14 \%$, available $\mathrm{P}=$ $160 \mathrm{mg} / \mathrm{kg}$, available $\mathrm{K}=250 \mathrm{mg} / \mathrm{kg}$.

Cucumber seeds used in this test were soaked with the bacterial cell suspension similar to those described for the sand tray test, except that each treatment had three pot replications (with 10 seeds per replication). After sowing, the pots were sprayed with tap water (twice a day; once in the morning and once in the afternoon) by handheld sprayer until the soil surface was completely wet in order to create an environment conducive for the development of pre-emergent damping-off disease. All of the pots were placed on the bench in the shade. Five days after sowing the cucumber seeds, the number of germinating seedlings was counted and the percentage of germinating seedlings was calculated and presented. However, disease symptoms on the root tissue were not checked. This is because the whole tested seedlings, which had collapsed, were desiccated and the diseased symptom on the root tissues could not be assessed. The disease assessment continued ten days after sowing and the disease symptoms were recorded. Dry weights of the seedlings were obtained after air drying in a hot air oven at $100^{\circ} \mathrm{C}$ for 24 hours.

\section{Statistical analysis}

Data collected were analysed using the $\mathrm{R}$ programme (Venables et al. 2019) computer software package. The mean ( \pm standard error) percentage of seed germinated, dried weight and percentage of germinating seedlings were compared using the Duncan's Multiple Range Test, $\mathrm{P}<0.05$.

\section{RESULTS}

SEM observation of the endospores of $B$. megaterium

SEM micrographs of a paper-based inoculum that had been stored in a Petri dish, or wrapped with sterile aluminum foil and stored in a ziplock plastic bag are shown in Figure 1. Bacterial endospores were not observed on the surface of filter paper that had not been inoculated with the endospore suspension of the bacterium (Fig. 1A). On the other hand, an aggregate of endospores was present on the filter paper surface after 135 days' storage (Figs. 1B \& 1C).

\section{Viability of B. megaterium endospores stored on paper}

The viability of endospores of the bacterium in the paper-based inoculum (wrapped with a sterile aluminium foil in the zip-lock plastic bag) declined initially, but then remained stable from 30 to 135 days of storage (Table 1 ). The viability 

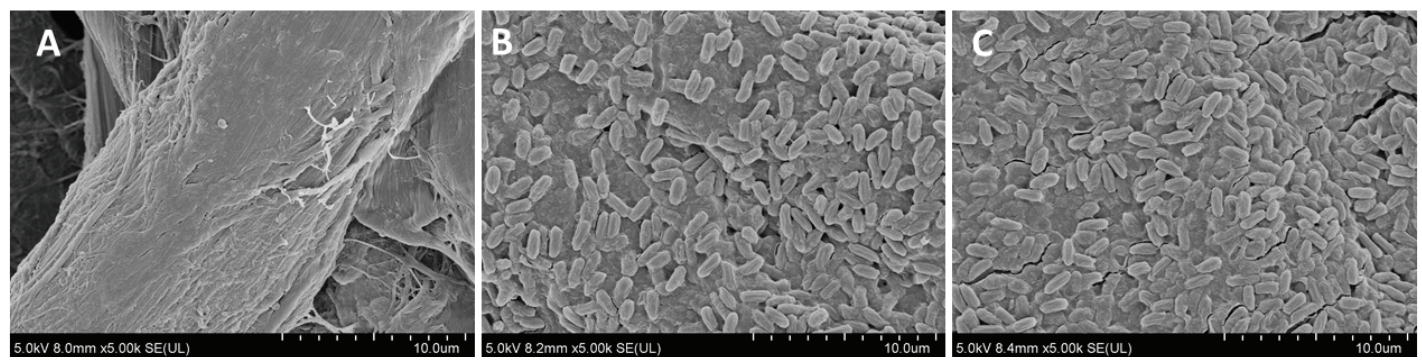

Figure 1 SEM micrographs (5000x magnification) of a paper-based inoculum prepared: (A) without bacterial endospores; (B) with endospores on the filter paper surface stored in sterile Petri dish; and (C) with endospores on the filter paper surface stored in a zip-lock plastic bag 135 days after storage at room temperature $\left(26-32^{\circ} \mathrm{C}\right)$.

of the paper-based inoculum (stored in the Petri dish) also decreased initially (from 15 to 75 days), but increased again at 90 days after storage (Table 1).

\section{Bacterial growth from the paper-based inoculum in the simple culture}

The number of bacteria endospores in the cultures peaked at day 3 , from the time a piece of paper-based inoculum of B. megaterium had been added in the simple culture (Table 2). The bacterial number dropped significantly at day 5 .
The number increased again and remained stable at days 7 and 9 .

Efficiency of simple culture of $B$. megaterium in promoting seed germination and seedling growth

The simple culture of $B$. megaterium reduced cucumber seed germination and the dry weights of yardlong bean (in the moist-chamber test) (Table 3). The mixture of B. megaterium and water (at $1: 15, \mathrm{v} / \mathrm{v}$ ) reduced cucumber seed germination (in the sand-tray test) (Table 4).

Table 1 Mean \pm standard error (SE) number of B. megaterium endospores (x106 CFU/strip of paper) from the paper strips $(1 \mathrm{~cm} \times 5 \mathrm{~cm}$ ) stored in Petri dish (for 150 days) and wrapped with aluminum foil in zip-lock plastic bag (for 135 days) at room temperature $\left(26-32^{\circ} \mathrm{C}\right.$ ). Means in each column followed by the same letter are not significantly different according to Duncan's multiple comparison test at $\mathrm{P}<0.05$.

\begin{tabular}{ccc}
\hline Days after storage & \multicolumn{2}{c}{ Number of endospores } \\
\cline { 2 - 3 } & Petri dish & Wrapped with aluminium foil \\
\hline 0 & $403.3 \pm 14.5 \mathrm{a}$ & $883.3 \pm 27.3 \mathrm{a}$ \\
15 & $32.0 \pm 2.5 \mathrm{~b}$ & $706.7 \pm 109.9 \mathrm{~b}$ \\
30 & $10.5 \pm 1.9 \mathrm{c}$ & $25.0 \pm 1.2 \mathrm{c}$ \\
45 & $6.3 \pm 0.3 \mathrm{c}$ & $55.7 \pm 22.5 \mathrm{c}$ \\
60 & $21.3 \pm 7.2 \mathrm{bc}$ & $35.7 \pm 10.7 \mathrm{c}$ \\
75 & $6.7 \pm 1.1 \mathrm{c}$ & $17.1 \pm 6.4 \mathrm{c}$ \\
90 & $31.0 \pm 10.4 \mathrm{~b}$ & $25.3 \pm 18.9 \mathrm{c}$ \\
105 & $9.4 \pm 0.2 \mathrm{c}$ & $7.1 \pm 0.9 \mathrm{c}$ \\
120 & $7.2 \pm 1.4 \mathrm{c}$ & $16.3 \pm 0.9 \mathrm{c}$ \\
135 & $16.0 \pm 0.6 \mathrm{bc}$ & $4.2 \pm 0.2 \mathrm{c}$ \\
\end{tabular}


Table 2 Mean number $( \pm \mathrm{SE}$ ) of $B$. megaterium endospores $\left(\mathrm{x} 10^{4} \mathrm{CFU} / \mathrm{mL}\right)$ at $1,3,5,7$ and 9 days after a piece of paper-based inoculum had been added to the simple culture containing CHFE. Means in each column followed by the same letter are not significantly different according to Duncan's multiple comparison test at $\mathrm{P}<0.05$.

\begin{tabular}{cc}
\hline Day & Number of bacteria \\
\hline 1 & $1.7 \pm 0.1 \mathrm{c}$ \\
3 & $189.0 \pm 11.0 \mathrm{a}$ \\
5 & $7.7 \pm 1.8 \mathrm{c}$ \\
7 & $61.0 \pm 17.1 \mathrm{~b}$ \\
9 & $77.3 \pm 8.4 \mathrm{~b}$ \\
\hline
\end{tabular}

Un-diluted simple culture of $B$. megaterium reduced seed germination but not the weight of cucumber seedlings; and the weight but not the germination of yardlong bean seedlings (Table 3 ). Diluted culture of $B$. megaterium (at $1: 10, \mathrm{v} / \mathrm{v}$ or $1: 15, \mathrm{v} / \mathrm{v}$ ) also reduced the germination of cucumber seeds (Table 4). More dilute cultures (at $1: 25$ or $1: 30, \mathrm{v} / \mathrm{v}$ ) increased seed germination but the effect was not statistically significant (Table 4). There were no significant differences in cucumber seedling weight for any of the culture dilutions used.

Pot-test efficacy of simple culture of $B$. megaterium to protect cucumber seeds from pre-emergent damping-off

The greatest percentage of germinated seedlings were found in treatments containing $B$. megaterium and water mixed at 1:5, 1:10 or
1:20 ratios (Table 5). There were no, or only few, healthy seedlings in the nil control or some treatments (at 1:15, v/v, 1:25, v/v and 1:30, v/v) (Table 5). However, all remaining healthy seedlings collapsed seven to ten days after sowing. The stems of the healthy seedlings became constricted at the soil surface before the collapse, followed by the decay of the whole seedlings.

\section{DISCUSSION}

The present study aims to: (1) produce simple inoculum of $B$. megaterium; (2) develop the simple technique to produce the active fresh cells of B. megaterium; and (3) test the efficacy of the bacterium in seed germination and disease control. These objectives are ambitious but they are required in order to make biological control measure accessible for use.

The technique used to produce the paperbased inoculum of $B$. megaterium in the present study was simple and effective, but there is room for technical improvement. For instance, using a pipette to dispense a suspension of bacterial endospores onto the surface of a filter paper strip may produce a final product with a lesser load of bacterial inoculum. Using this technique, the number of viable endospore was at around 4 $\mathrm{x} 10^{6} \mathrm{CFU} /$ strip of paper after 150 days of storage (Table 1). However, soaking the filter paper in a suspension of bacterial endospores should increase the number of bacteria on the paperbased inoculum and this increased inoculum load should prolong the shelf life of the paper-based inoculum. Nevertheless, the results of this study

Table 3 Mean $( \pm$ SE) percentage of seed germination and dried weights of yardlong bean and cucumber seedlings after seed pre-treatment with or without undiluted simple culture of B. megaterium in the moist-chamber test. Means in each column followed by the same letter are not significantly different according to Duncan's multiple comparison test at $\mathrm{P}<0.05$.

\begin{tabular}{lcc}
\hline \multicolumn{1}{c}{ Treatment } & Germination (\%) & Dried weight $(\mathrm{g})$ \\
\hline Yardlong bean seeds with bacterium & $87.3 \pm 2.7 \mathrm{c}$ & $56.0 \pm 3.7 \mathrm{~b}$ \\
Yardlong bean seeds with sterile water & $87.5 \pm 1.8 \mathrm{c}$ & $79.8 \pm 4.5 \mathrm{a}$ \\
Cucumber seeds with bacterium & $93.0 \pm 1.1 \mathrm{~b}$ & $57.5 \pm 4.3 \mathrm{~b}$ \\
Cucumber seeds with sterile water & $98.8 \pm 0.6 \mathrm{a}$ & $59.2 \pm 3.8 \mathrm{~b}$ \\
\hline
\end{tabular}


Table 4 Mean $( \pm S E)$ percentage of seed germination and dried weights of cucumber seedlings after seed pre-treatment with different dilutions of the simple culture of $B$. megaterium or water in the sandtray test. Means in each column followed by the same letter are not significantly different according to Duncan's multiple comparison test at $\mathrm{P}<0.05$.

\begin{tabular}{lcc}
\hline \multicolumn{1}{c}{ Treatment } & Germination $(\%)$ & Dried weight $(\mathrm{g})$ \\
\hline Sterile water & $86.0 \pm 6.7 \mathrm{a}$ & $89.6 \pm 0.8 \mathrm{a}$ \\
$1: 5$ (bacterial cell suspension : water) & $88.0 \pm 4.4 \mathrm{a}$ & $91.0 \pm 0.7 \mathrm{a}$ \\
$1: 10$ (bacterial cell suspension : water) & $78.0 \pm 5.5 \mathrm{bc}$ & $91.3 \pm 0.6 \mathrm{a}$ \\
$1: 15$ (bacterial cell suspension : water) & $64.0 \pm 5.0 \mathrm{c}$ & $90.2 \pm 1.1 \mathrm{a}$ \\
$1: 20$ (bacterial cell suspension : water) & $88.0 \pm 5.3 \mathrm{ab}$ & $89.8 \pm 1.0 \mathrm{a}$ \\
$1: 25$ (bacterial cell suspension : water) & $96.0 \pm 2.7 \mathrm{a}$ & $89.3 \pm 1.5 \mathrm{a}$ \\
$1: 30$ (bacterial cell suspension : water) & $94.0 \pm 4.3 \mathrm{a}$ & $90.1 \pm 0.5 \mathrm{a}$ \\
\hline
\end{tabular}

Table 5 Mean $( \pm$ SE) percentage of seed germination of cucumber after these seeds were soaked with different dilutions of the simple culture of B. megaterium or sterile water in the pot test. Means in each column followed by the same letter are not significantly different according to Duncan's multiple comparison test at $\mathrm{P}<0.05$.

\begin{tabular}{lc}
\hline \multicolumn{1}{c}{ Treatment } & Germination (\%) \\
\hline Sterile water & $0.0 \pm 0.0 \mathrm{c}$ \\
$1: 5$ (bacterial cell suspension : water) & $50.0 \pm 15.3 \mathrm{ab}$ \\
$1: 10$ (bacterial cell suspension : water) & $70.0 \pm 5.8 \mathrm{a}$ \\
$1: 15$ (bacterial cell suspension : water) & $13.3 \pm 13.3 \mathrm{bc}$ \\
$1: 20$ (bacterial cell suspension : water) & $46.7 \pm 18.6 \mathrm{ab}$ \\
$1: 25$ (bacterial cell suspension : water) & $3.3 \pm 3.3 \mathrm{c}$ \\
$1: 30$ (bacterial cell suspension : water) & $20.0 \pm 11.6 \mathrm{bc}$ \\
\hline
\end{tabular}

indicate that dried endospores of B. megaterium on filter paper can be used for a starter culture of this BCA. Storage of the spore-impregnated filter paper in an aluminium foil wrap inside a zip-lock bag produced more viable cells than storage in a Petri dish. Therefore, exposing the paper-based inoculum of $B$. megaterium to air, humidity, light and UV-radiation may have had an effect on the bacterial population. Viability of endospores of B. anthracis and B. subtilis declined substantially when the endospores were exposed to simulated sunlight, using ultraviolet (UV)-A/B radiation (Wood et al. 2015). The effect of storage conditions to the viability of the bacterium thus requires further investigation.

The simple culture of $B$. megaterium in a seasoning cube using fresh cells of $B$. megaterium as a starter produced the stable number of $B$. megaterium over time (Kanjanamaneesathian \& Meetum 2019). However, the fluctuation of the number of $B$. megaterium associated with culture studies using paper-based inoculum as a starter (Table 2), that did not fit the sigmoid growth curve, indicated that further culture experiments are required to establish the pattern of the bacterial growth.

The negative effects of the simple culture of $B$. megaterium in reducing cucumber seed germination (Table 3 and Table 4) and the dry weights of yardlong bean (in the moist-chamber test) (Table 3) indicated that the optimal population of the bacterium for application to 
plants must be ascertained to ensure that the applied bacterium has a positive impact on the plants. Chobotarova et al. (2015) reported that treating cucumber seeds with $10^{7} \mathrm{CFU} / \mathrm{mL}$ of Bacillus subtilis B-7023 IMV (which produced indole-3-acetic acid (IAA) and amino acids in the liquid medium, resulted in a decrease in the length of the roots of plants. When those seeds were treated with a reduced load of the bacterium (at $10^{6} \mathrm{CFU} / \mathrm{mL}$ ), the length of roots, shoots and total plant mass were increased. This research work (Chobotarova et al. 2015) reiterated the significance of the level of the applied bacterium to plant. As our study did not determine the number of the applied bacterium, more experiments are needed before any useful recommendations shall be available to the farmers to apply B. megaterium to cucumber and yardlong bean.

The fresh cells of $B$. megaterium that produced from the paper-based inoculum as a starter only provided early protection to seeds of the cucumber against damping-off disease (Table 5). Nevertheless, the fact that all cucumber seedlings succumbed to post-emergent damping-off disease indicated that control efficacy of this bacterium is transient. Although the diluted culture of $B$. megaterium (at 1:10, v/v) has been recommended to rice farmers for use as either seed treatment for growth promotion or foliar application for GD suppression (Kanjanamaneesathian \& Meetum 2019), more research work to optimise the suitable dose of bacterial number for these cash crops is required.

Overall, repeat experiments in both the culture study and the efficacy tests are needed to determine the best concentration of BCA to use to achieve a balance between good disease control and adverse effects on the plant.

\section{CONCLUSIONS}

Endospores of B. megaterium remain viable and effective on the filter paper for a period of 150 days of storage. A paper-based inoculum of $B$. megaterium has the potential to use as a starter to culture the bacterium using the simple culture technique. This culture has the potential to be used with cucumber to promote seed germination and to protect cucumber seeds from pre-emergent damping-off disease. However, more research is needed to establish the best concentration of the bacterial culture to use for seed treatment and to determine its effect to different damping-off pathogens.

\section{ACKNOWLEDGEMENTS}

The authors would like to thank the Faculty of Animal Science and Agricultural Technology (ASAT), Silpakorn University (SU), Phetchaburi IT campus, Cha-Am, Phetchaburi for laboratory facilities. The local office of the Land Development Department at Phetchaburi and Ratchaburi, Ministry of Agriculture and Agricultural Cooperatives, Thailand, kindly assists in analysing the soil sample. ASAT is also appreciated to support the first author to present this research at the New Zealand Plant Protection Society conference 2019.The authors appreciate the kind assistance of Mr. Peter Matthew Bauer, an English teacher, Faculty of ASAT, SU, for proofreading the manuscript and anonymous reviewers for suggesting valuable improvements to the text.

\section{REFERENCES}

Agrios GN 2005. Plant Pathology. Academic Press, Gainesville, USA, 952 p.

Chilvers GA, Douglass PA, Lapeyrie FF 1986. A paper sandwich technique for rapid synthesis of ectomycorrhizas. New Phytologist 103: 397-402.

Chobotarova VV, Bega ZT, Kurdish IK 2015. Physiological and biochemical activity of bacteria during germination of cucumber seeds and impact of ciliates Colpoda steinii on this process. Mikrobiologicheskii zhurnal 77: $15-21$.

ChumthongA, Kanjanamaneesathian M,Pengnoo A, Wiwattanapatapee R 2008. Water-soluble granules containing Bacillus megaterium for biological control of rice sheath blight: Formulation, bacterial viability and efficacy testing. World Journal of Microbiology and Biotechnology 24: 2499-2507. 
Chumthong A, Wiwattanapatapee R, Viernstein $\mathrm{H}$, Pengnoo A, Kanjanamaneesathian M 2016. Spray-dried powder of Bacillus megaterium for control of rice sheath blight disease: formulation protocol and efficacy testing in laboratory and greenhouse. Cereal Research Communications 44: 131-140.

Kanjanamaneesathian M, Kusonwiriyawong C, Pengnoo A, Nilratana L 1998. Screening of potential bacterial antagonists for control of sheath blight in rice and development of suitable bacterial formulations for effective application. Australasian Plant Pathology 27: 198-206.

Kanjanamaneesathian M, Chumthong, A, Pengnoo A, Wiwattanapatapee R 2009. Bacillus megaterium suppresses major Thailand rice diseases. Asian Journal of Food and Agro-Industry (Special Issue): 154-159.

Kanjanamaneesathian M, Meetum P 2017. Efficacy of a simple liquid culture of Bacillus megaterium in suppressing grain discoloration disease of rice (Oryza sativa). New Zealand Plant Protection 70: 196-202.

Kanjanamaneesathian M, Meetum P 2019. Comparison of aqueous seasoning cube solution and nutrient broth as culture media for production of the biocontrol agent, Bacillus megaterium in the laboratory, and for suppression of rice grain discolouration in the field. New Zealand Plant Protection 72: 205-212.

Malusá E, Sas-Paszt L, Ciesielska J 2012. Technologies for beneficial microorganisms inocula used as biofertilizers. The Scientific World Journal 2012: 1-12.

Pengnoo A, Kusongwiriyawong C, Nilratana L, Kanjanamaneesathian M 2000. Greenhouse and field trials of the bacterial antagonists in pellet formulations to suppress sheath blight of rice caused by Rhizoctonia solani. BioControl 45: 245-256.

Venables WN, Smith DM, R Core Team 2019. An Introduction to $\mathrm{R}$ : Notes on $\mathrm{R}$ : A programming environment for data analysis and graphics version 3.6.0. Vienna, Austria. $99 \mathrm{p}$.
Warburton H, Ketunuti U, Grzywacz D 2002. A survey of the supply, production and use of microbial pesticides in Thailand, NRI Report 2723. Natural Resources Institute, University of Greenwich, Chatham.100 p.

Wiwattanapatapee R, Pengnoo A, Kanjanamaneesathian M, Matchavanich W, Nilratana L, Jantharangsri A 2004. Floating pellets containing bacterial antagonist for control sheath blight of rice: formulation, viability and bacterial release studies. Journal of Controlled Release 95: 453-460.

Wiwattanapatapee R, Chumthong A, Pengnoo A, Kanjanamaneesathian M 2007. Effervescent fast-disintegrating bacterial formulation for biological control of rice sheath blight. Journal of Controlled Release 119: 229-235.

Wiwattanapatapee R, Chumthong A, Pengnoo A, Kanjanamaneesathian M 2013. Preparation and evaluation of Bacillus megateriumalginate microcapsules for control of rice sheath blight disease. World Journal of Microbiology and Biotechnology 29: 14871497.

Wood JP, Meyer KM, Kelly TJ, Choi YW, Rogers JV, Riggs KB, Willenberg ZJ 2015. Environmental persistence of Bacillus anthracis and Bacillus subtilis spores. PLoS ONE 10, e0138083. 